\title{
Hal-Ihwal Jumlah Ismiyah Dalam Bahasa Arab
}

\author{
Oleh : Rappe ${ }^{1}$
}

\begin{abstract}
Abstrak
Tulisan ini mengungkapkan tentang macam-macam bentuk jumlah ismiyah dalam Bahasa Arab. Di sini diungkapkan bagaiman unsur jumlah ismiyah yang terdiri dari mubtada' dan khabar dipahami dan diperlakukan sesuai kaidah bahasa Arab, sehingga akan ditemukan kaidah-kaidah yang mewajibkan mubtada' selalu didahulukan dari khabar, kaidah-kaidah yang mewajibkan khabar didahulukan dari mubtada', kaidahkaidah yang mewajibkan mubtada' tidak disebutkan dalam kalimat, dan kaidah-kaidah yang mewajibkan khabar tidak disebutkan dalam kalimat.
\end{abstract}

Kata Kunci : Jumlah ismiyah-kaidah mubtada’ dan khabar-variasi bentuk jumlah ismiyah.

\section{PENDAHULUAN}

Struktur jumlah ismiyah yang dimaksud dalam tulisan ini adalah struktur kalimat bahasa Arab yang terdiri dari mubtada' dan khabar. Mubtada'adalah setiap isim yang berada di awal kalimat jumlah ismiyah atau disebut subyek dalam kaidah bahasa Indonesia, sedangkan khabar adalah pelengkap kalimat jumlah ismiyah atau disebut juga predikat dalam kaidah bahasa Indonesia yang biasa terdiri kata isim (jamid dan musytaq) ${ }^{1}$, kata keterangan waktu atau tempat, dan atau kalimat, yang mana hukum i'rab khabar mengikuti mubtada'.

Menurut Fu'ad Ni'mah bahwa:

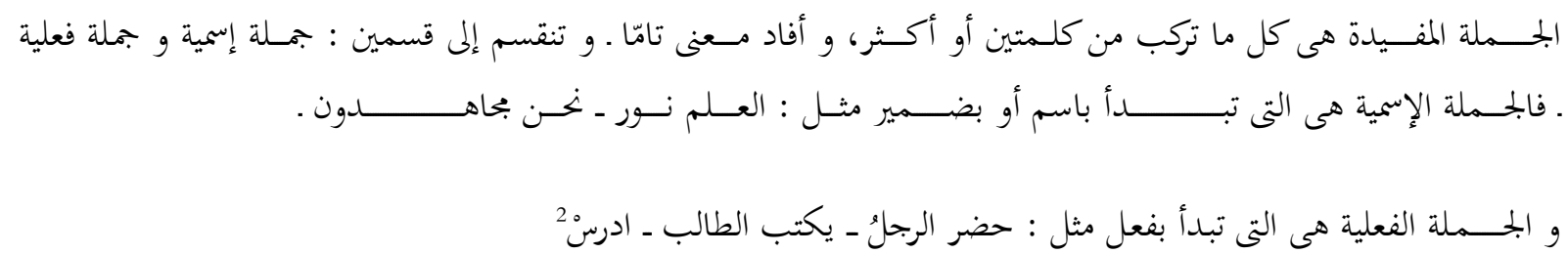

Artinya:

Jumlah mufidah adalah seluruh struktur bahasa yang terdiri dari dua kata atau lebih, dan struktur bahasa tersebut memiliki arti yang lengkap. Jumlah mufidah terbagi at as dua bahagian yaitu jumlah ismiyah dan jumlah fi' iliyah. Jumlah ismiyah adalah struktur kalimat yang diawali dengan isim atau damir contoh: 'Ilmu itu adalah cahaya' - 'Kami adalah para pejuang', sedangkan jumlah fi'iliyah adalah struktur kalimat yang diawali dengan fi'il (kata kerja), contoh: 'Laki-laki itu telah datang' 'Mahasiswa itu sedang menulis' - 'Belajarlah !'

${ }^{1}$ Isim musytaq ditinjau dari segi ilmu sharaf adalah terdiri dari bentuk mashdar, isim fa'il, shifat musyabbahah biismi al-fail, isim maf'ul, isim makan, isim zaman, isim alat, dan isim tafdhil sebagaimana yang terdapat dalam Al-syeikh Ahmad Al-hamlawi, Syatz Al-'urf fi Al-sharf, (Cet. XVI; Mesir: Syirkah Maktabah Mushthafa al-Tsaniy al-Halbiy wa Auladuh, 1384 H/1965 M), h. 68

${ }^{2}$ Fuād Ni'mah, Mulakhkhas Qawā'id al-Lughah al-Arabiyah, (Bairut: Dār al-Ṣaqāfah al-Islāmiyah, t.th), h. 19 
Menurut Ahmad Qabbisy bahwa:

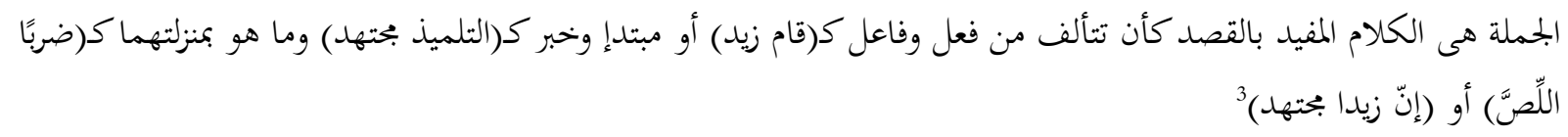

Artinya:

Jumlah adalah kalimat yang memiliki makna dengan maksud tertentu, seperti terdiri dari struktur fi'il dan fa'il contoh (Zaid telah berdiri) atau struktur mubtada' dan khabar contoh (Siswa itu adalah rajin) struktur kalimat yang menyerupai keduanya contoh (pukullah pencuri itu) dan (sesungguhnya Zaid itu adalah rajin)

Antara mubtada' dan khabar keduanya harus sesuai dari segi bentuk mufradnya, mutsanna'nya, dan jamaknya apabila mubtada' itu terdiri dari isim yang berakal (manusia), tapi kalau terdiri dari isim yang tidak berakal maka keduanya hanya disesuaikan dari segi mufrad dan mutsanna'nya saja, ${ }^{4}$ karena apabila mubtada' terdiri dari isim yang tidak berakal (benda atau hewan) maka khabarnya berbentuk mufrad muannats.

Fokus bahasan dalam jurnal ini adalah kaidah penyusunan struktur jumlah ismiyah dengan deskripsi fokusnya adalah :

1. Bagaimana hal-ihwal bentuk mubtada' dan khabar sebagai unsur struktur jumlah ismiyah?

2. Bagaimana variasi bentuk struktur jumlah ismiyah?

\section{PEMBAHASAN}

Sebelum berbicara mengenai jumlah ismiyah (الجملة الاسمية) terlebih dahulu penting dibicarakan unsur jumlah ismiyah sebagai syarat terbentuknya jumlah ismiyah itu sendiri. Adapun unsur dari pada jumlah ismiyah ada dua hal yaitu mubtada' dan khabar. Mubtada' sebagai mana dijelaskan di atas adalah isim yang berada di awal kalimat yang berposisi sebagai subyek dalam kalimat atau jumlah, sedangkan khabar adalah isim atau kalimat atau keterangan yang berposisi sebagai predikat dalam sebuah kalimat sehingga kalimat itu menjadi sempurna. ${ }^{5}$

\section{A. Bentuk-Bentuk Mubtada (المبتأ))}

\section{Macam-Macam Mubtada}

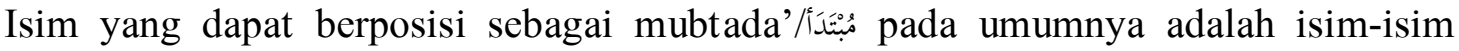
ma'rifah, dan sebahagian kecil ada yang terdiri dari isim nakirah. ${ }^{6}$ Selain itu mubtada'

\footnotetext{
${ }^{3}$ Ahmad Qabbisy, al-kāmil fì 'Ilm al-Nahw wa al-Śarf wa al- 'Irāb, (Bairut-Libnān: Dār al-Jail) h. 221

${ }^{4}$ Al-Duktur Al-Fakhriy Al-hajj Mustafa Muhammad Nuri, LAS wa Al-Hajjah Hafsah Intan, LC, AlArabiyah Al-Muyassarah, (Cet. I; Makassar: Pustaka Arif, 2008), h. 31 t.th), h. 30

${ }^{5}$ Fuad Ni'mah, Mulakhkhash Qawaid al-Lughah al-Arabiyah, (Bairut: Dar al-Tsaqafah al-Islamiyah, 1999), h. 36

${ }^{6}$ al-Hajj Musthofa Muhammad Nuri, al-'Arabiyah al-Muyassaroh, (jilid II; Ujung Pandang: Berkah Utami,
} 
kadang-kadang terdiri dari isim majrur dengan huruf jar zaidah (tambahan) dan mashdar muawwal.

Adapun isim ma'rifah yang dimaksud adalah :

1. Isim ‘alam ( إِسْمُ الْعَلَمِ )

contoh-contoh kalimatnya adalah sebagai berikut :

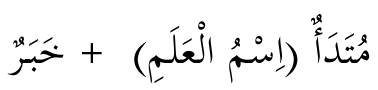

\begin{tabular}{|c|c|}
\hline Ahmad adalah seorang yang cerdas & أَحْمَدُ + ذَكَىُْْ \\
\hline Ali berada di muka kelas & عَلِيُّ + أَمَامَ الْفَصْلِ \\
\hline Amerika adalah sebuah negara yang besar & أَمْرِيْكَا + بَلْلَةَهُ كَبِيْرَة \\
\hline Jepan adalah sebuah negara maju & يَابَانُ + بَلْلَدُة مُتَقَدَدِّمَةُ \\
\hline Prancis adalah terletak di Eropa & فَرَنُُْ + تَقَعُعُ فِ أُرُوْْبَا \\
\hline
\end{tabular}

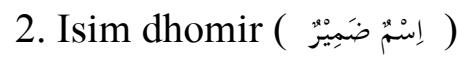

Adapun pola dan contoh-contoh kalimatnya adalah sebagai berikut :

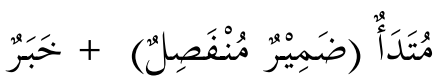

\begin{tabular}{|c|c|}
\hline Dia laki-laki & هُوَ + مُدَرِّمعْ \\
\hline Mereka dua laki-laki & هُمَا + مُوَظَفَانِ رِنَ الجَحَامِعَةِ \\
\hline Mereka jamak laki-laki & هُمْ + مُقَاولَوْْنَ \\
\hline Dia wanita & هِيَ + مُضِيْفَةُ \\
\hline Mereka dua wanita & هُمُا + مُمرِّضِضَتَانِ \\
\hline Mereka jamak wanita & هُنَّ + مُغَنِيَّاتُ \\
\hline
\end{tabular}

3. Isim Isyarah ( إسنمُ الْإِشَارَة )

pola dan contoh-contoh kalimatnya berikut ini :

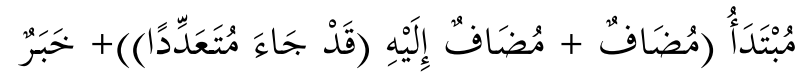




\begin{tabular}{|c|c|}
\hline Buku dosen itu baru & 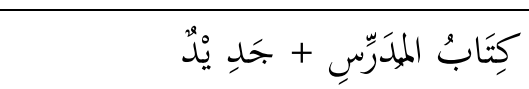 \\
\hline Meja dosen (wanita) fikhi itu persegi panjang & مَكْتَبُ مُدَرَسَسَةِ الْفِقْهِهِ + مُسنتَطِيْلِ \\
\hline $\begin{array}{l}\text { Warna meja dosen (wanita) fikhi itu persegi } \\
\text { panjang }\end{array}$ & لَوْنُ مَكْتَبِ مُدَرَّسَةِ الْفِقْهِ + مُسنتَطِيْلِ \\
\hline $\begin{array}{l}\text { Warna mobil dekan fakultas Tarbiyah itu } \\
\text { hitam }\end{array}$ & 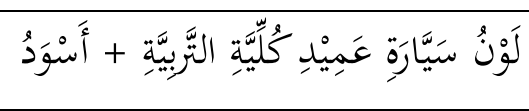 \\
\hline
\end{tabular}

4. Isim maushul ( إسنمُ الْمَوْصُوْلِ )

pola penerapan dan contoh-contohnya dalam jumlah ismiyah berikut ini :

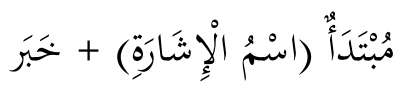

\begin{tabular}{|c|c|}
\hline Ini sebuah kemeja & هَذًَا + قَمِيْصُ \\
\hline Ini adalah dua buah kemeja & هَذَانِ + قَمِيْصَانِ \\
\hline Ini adalah kemeja-kemeja & هَذَِِِ + قُمْصَانُ \\
\hline Mereka ini para dosen & هَوُْلاٍَِ + مُدَرِّسُوْنَ \\
\hline
\end{tabular}

5. Isim yang beralif-lam ( " دَخَلَ عَلَيْهِ " الْ )

pola dan contoh-contoh kalimat yang diawali dengan isim maushul berikut ini :

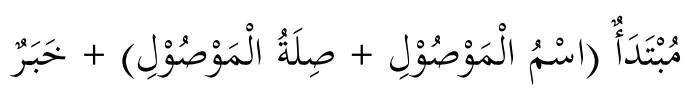

\begin{tabular}{|c|c|}
\hline $\begin{array}{l}\text { Orang (laki-laki) yang sedang bercakap } \\
\text { bahasa Arab dengan lemah-lembut itu adalah } \\
\text { mahasiswa tauladan }\end{array}$ & اللُّغَةَ الْعَرَبيَّةَ سَلِسًا طَالِلِبْ \\
\hline $\begin{array}{l}\text { Kedua orang (laki-laki) y } \\
\text { bahasa Arab dengan leme } \\
\text { mahasiswa tauladan }\end{array}$ & 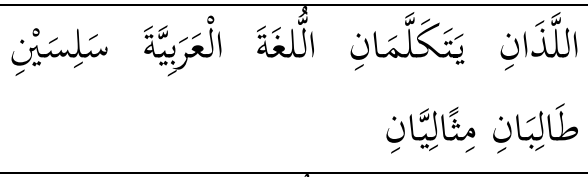 \\
\hline $\begin{array}{l}\text { Mereka (laki-laki) y } \\
\text { bahasa Arab dengan } \\
\text { para mahasiswa taul }\end{array}$ & 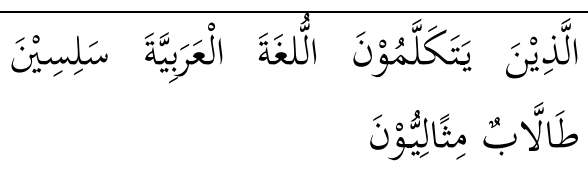 \\
\hline $\begin{array}{l}\text { Orang (wanita) yang s } \\
\text { Arab dengan lemah-ler } \\
\text { mahasiswi tauladan }\end{array}$ & 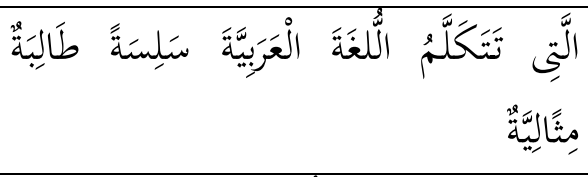 \\
\hline $\begin{array}{l}\text { Dua orang (wanita) yang sedang bercakap } \\
\text { bahasa Arab dengan lemah-lembut itu adalah } \\
\text { mahasiswi tauladan }\end{array}$ & الْعَربيَّةَ سَلِسَتَيْنِ \\
\hline
\end{tabular}




\begin{tabular}{|c|c|}
\hline $\begin{array}{l}\text { Mereka (wanita) yang sedang bercakap } \\
\text { bahasa Arab dengan lemah-lembut itu adalah } \\
\text { para mahasiswi tauladan }\end{array}$ & 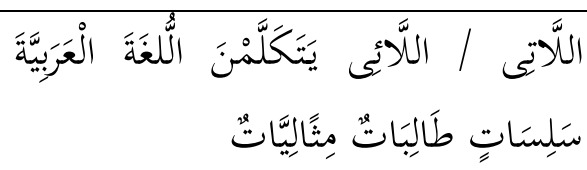 \\
\hline
\end{tabular}

6. Isim yang mudhof ( اسنمُ الْمُضَافِ

pola penerapannya dalam kalimat ketika berposisi sebagai mubtada' disertai contohcontohnya

$$
\text { مُبْتَدَأ ( الْ + اسْمُ ظَاهِرِّ ) + خَبَرِّ }
$$

\begin{tabular}{|c|c|}
\hline Wartawan (laki-laki) itu jujur & الصَّحْنِفى + صَادِقِق \\
\hline Wartawan (wanita) itu jujur & الصَّحْفِيَّةُ + صَادِقَة \\
\hline Dua wartawan (laki-laki) itu jujur & الصَّحْفِليَّانِ + صَادِقَانِ \\
\hline Dua wartawan (wanita) itu jujur & الصَّحْفِيَّنَانِ + صَادقِقَتَانِ \\
\hline Para wartawan (laki-laki) itu jujur & الصَّحْفِيُوْنَ + صَادِقِوْنَ \\
\hline Para wartawan (wanita) itu jujur & الصَّحْفِيَّاتُ + صَادِقًَاتُ \\
\hline
\end{tabular}

7. Mubtada' dari isim nakirah

Adapun syarat-syarat yang harus dipenuhi apabila isim nakirah diposisikan sebagai mubtada' dalam suatu kalimat bahasa adalah isim maushuf/ إسنمْ مَوْصُوْفَ" (kata benda yang

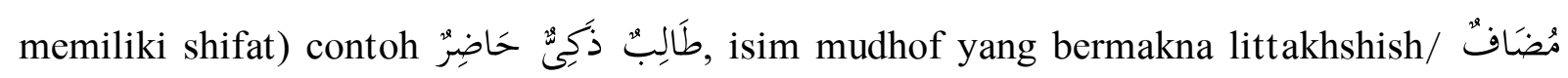

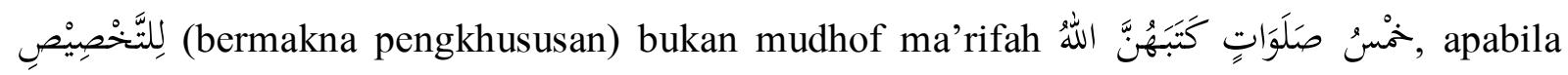

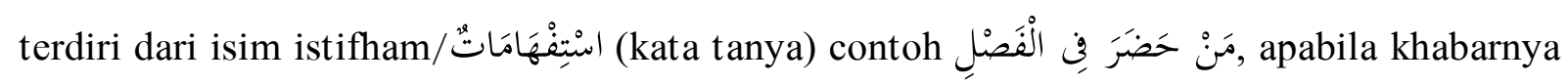

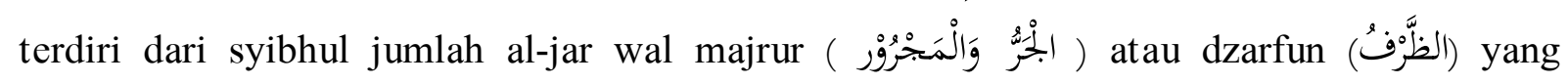
didahulukan dari mubtada' contoh فِفِ الدَّارِ وَلََدَانِ, apabila khabar itu lebih ditekankan dalam kalimat dari pada mubtada' dengan cara menggunakan kata sesungguhnya ( إِنَّمَ $)$ atau huruf

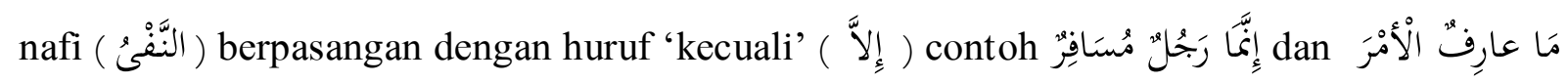

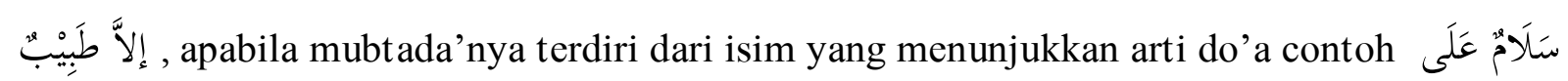
, إبْرَاِِيْمَ apabila mubtada'nya terdiri dari isim yang menunjukkan arti sebahagian yang dilambangkan dengan kata بَعْ لُّ نُ dan keseluruhan yang dilambangkan dengan kata

\footnotetext{
${ }^{7}$ Rappe, Ilmu Nahwu Dasar Dan Pola-Pola Penerapannya Dalam Kalimat (Cet. I; Makassar: Alauddin University Press, 2013), h. 82
} 


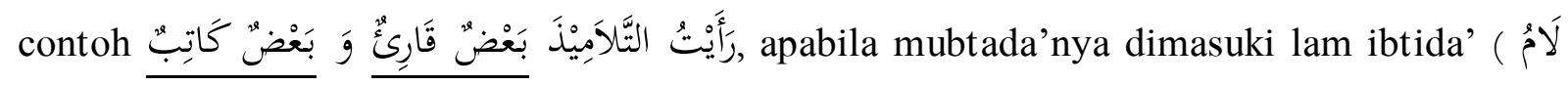

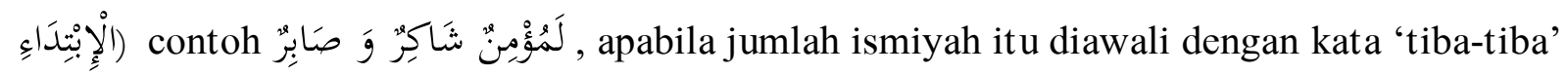

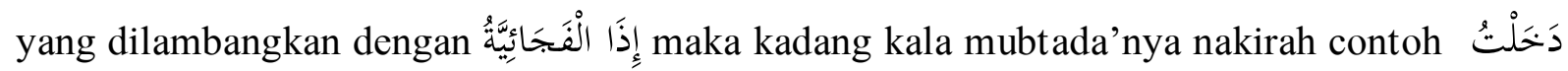

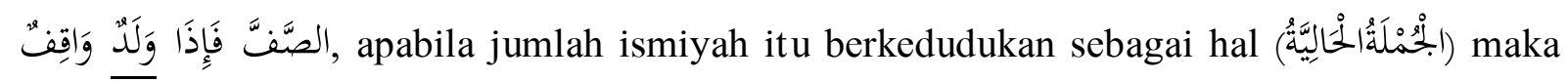
kadang-kadang mubtada'nya terdiri dari isim nakirah contoh dan

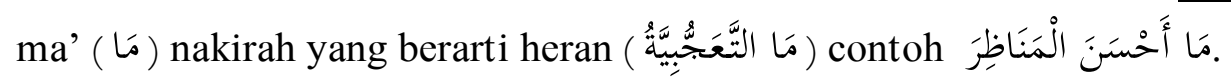

8. Mashdar muawwal/المصدر المؤول

Mashdar muawwal adalah gabungan dari huruf mashdar an ( أنْ ) dengan fi'il sesudahnya yang takwil menjadi mashdar sehingga ia dapat menempati posisi 'irab sesuai أنْ تَصُوْمُوْا adalah mashdar muawwal fi mahalli raf'in mubtada'.

Inilah delapan hal dari bentuk-bentuk kata yang dapat menjadi mubtada' . Dengan demikian apabila jumlah ismiyah yang disusun dalam bahasa Arab tidak terlepas dari menggunakan salah satu kata yang dapat menduduki posisi mubtada' di atas.

\section{Macam-Macam Khabar} jumlah $^{10}$ :

Khabar terbagi menjadi tiga, yaitu khabar mufrad, khabar jumlah, dan khabar syibhul a. Khabar Mufrad(المفرد)

Khabar Mufrad (المفرد) yaitu khabar yang bukan berbentuk kalimat atau yang menyerupai kalimat, akan tetapi terdiri dari satu kata baik menunjukkan pada tunggal atau mutsanna (bentuk dua) ataupun jamak, istilah ini juga biasa disebut khabar isim ( الخبر (الإسمىى dan harus disesuaikan dengan Mubtada dalam pentazkiran (berbentuk muzakkarf = lk) atau ta'nis juga dalam bentuk tunggal, mutsanna dan jamak. Contoh ( القمر منير = bulan bersinar), (الطالبة مؤدبة = pelajar perempuan itu sopan).

\footnotetext{
${ }^{8}$ Ibid. h. 60

${ }^{9}$ Jurjis Isa Al Asmar, Qamus al-'Irab, (Dar al-Ilmi li al-Malayin; Bairut : t.th), h. 18

${ }^{10}$ Abubakar Muhammad, Ilmu Nahwu : Teori Praktis Untuk Menguasai Tata Bahasa Arab, (Surabaya: Karya Abditama, 1996), h. 130

${ }^{11}$ Ahmad Yazid dan Umar Hubeis, Belajar Mudah Ilmu Nahwu Shoraf, (jilid I , Cet. I; Surabaya: Pustaka Progressif, 2011), h. 127
} 


\section{b. Khabar Jumlah (جملة)}

Khabar Jumlah (جملة), yaitu khabar yang berbentuk kalimat baik jumlah ismiah (اسمية) maupun jumlah fi'liyah (فعليه), kedua jumlah tersebut apabila berposisi sebagai khabar maka posisi 'irab keduanya adalah dianggap seperti khabar mufrad hanya saja tempatnya yang dirafa' atau dalam istilah ilmu Nahwu adalah ( فى محل رفع (a) . Contoh khabar jumlah ismiah = taman itu pepohonannya berwarna hijau) atau (الثوب لونه أبيض = الحيقة أشجارها خضراء) pakaian itu warnanya bersih), Atsaub = adalah mubtada' pertama, لون= Mubtada kedua dan mudhaf, dhamir أبيض = = mudhaf ilaih, khabar mubtada kedua, Jumlah dari mubtada kedua dan khabarnya menempati posisi rafa' yaitu khabar dari mubtada pertama. Adapaun contoh khabar mubtada dari jumlah fi'liyah, (يلعبون في الحديقة الأطفال = anak-anak bermain di taman) يلعبون adalah fi'il mudhari'marfu'karena khabar mubtada yang berbentuk jumlah fi'liyah. Khabar jumlah baik ismiah maupun fi'liyah harus disesuaikan dengan mubtada.

\section{c. Khabar syibhu jumlah (شبه الجملة)}

Khabar syibhu jumlah (شبه الجملة) yaitu khabar yang bukan mufrad atau jumlah akan tetapi menyerupai jumlah, terdiri dari jarr wal majrur (جار ومجرور) dan dharf=kata keterangan,(ظرف). (ظار ومجرور) dan dharf

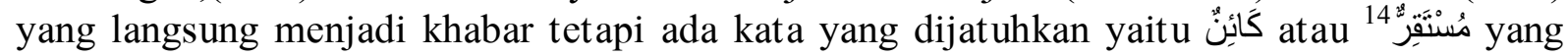

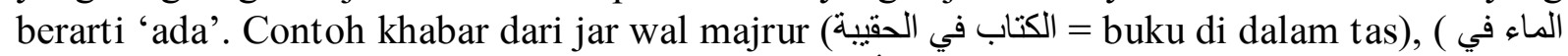
air di dalam teko) asalnya adalah الإبريق الإيق كَائنُ في الإبريق Contoh khabar dari dharf makan (keterangan tempat), (الجنة تحت أقدام الأمهاتsurga dibawah telapak kaki ibu) asalnya adalah الطائر فوق ) demikian pula contoh-contoh kalimat yang lain seperti , الجنة كَائنة تحت أقدام الأمهات = الرحلة يومَ الخميس (الثجرة (عurung di atas pohon), contoh dharf zaman (keterangan waktu), bepergian pada hari kamis), (السفر بعد أسبوع = akan bepergian setelah seminggu).

\section{B. Macam-Macam Bentuk Jumlah Ismiyah}

\section{Wajib Mendahulukan Mubtada}

Mubtada itu wajib didahulukan apabila:

a. Isim yang mempunyai kedudukan sebagai pendahuluan di dalam kalimat, seperti isim syarat, atau istifham atau Ma yang menunjukkan ketakjuban, contohnya ( من barangsiapa yang membaca syair maka akan bertambah kekayaannya dengan bahasa), kata Man di sini adalah mubtada yang harus di dahulukan karena posisinya dalam kalimat sebagai pembukaan dan pendahuluan, contoh lain ( مسافر غدا من = siapakah yang akan bepergian besok), kata man di sini adalah kata Tanya yang harus selalu didahulukan dan ia adalah mubtada, contoh lain (ما أجمل الربيع=alangkah indahnya musim semi) Kata Ma disini adalah Ma takjub yang mana harus dan wajib didahulukan.

\footnotetext{
${ }^{12}$ Fuad Ni'mah, Op. Cit., h. 32

${ }^{13}$ Fuad Ni'mah, OP Cit, h. 31

${ }^{14}$ Syeikh Syamsuddin Muhammad Arra'ini, Mutammimah Ajurumiyah diterjemahkan oleh Moch. Anwar dkk dengan judul IImu Nahwu, (Cet.XIX; Bandung : Sinar Baru Algesindo, 2016), h. 151
} 
b. Mubtada yang menyerupai isim syarat, contohnya (الذي يفوز فله جائزة) = yang menang maka baginya piala), kata allazi dalam kalimat ini menyerupai isim syarat.

c. Isim tersebut haruslah disandarkan kepada isim yang menempati posisi dan kedudukan kata pendahuluan, contohnya (عمل من أعجبك) kata 'amal disandarkan pada Man yang kedudukannya sebagai pendahuluan.

d. Apabila khabarnya adalah jumlah fi'liyah dan fa'ilnya adalah dhamir yang tersembunyi yang kembali kepada mubtada, contohnya محد يلعب الكرة) =Muhammad bermain bola) kata yal'ab adalah khabar jumlah fi'liyah dan fa'ilnya dhamir tersembunyi kembali ke Muhammad.

e. Isim tersebut haruslah disertai dengan huruf Lam untuk memulai atau Lam tauwkid, contoh (وللار الآخرة خير للذين يتقون) kata addar dimasuki oleh lam ibtida, dan (ولذكر الله أكبر) dimasuki lam tawkid.

f. Mubtada dan khabarnya adalah Ma'rifat atau kedua-duanya nakirah dan tidak adanya kata yang menjelaskannya, contohnya (أبوك محمد) jika ingin memberitahukan tentang bapaknya maka wajib didahulukannya, dan (محمد أبوك) jika ingin memberitahukan tentang Muhammad.

g. Mubtada teringkas khabarnya oleh Illa atau Innama, contohnya (ما الصدق إلا فضيلة) dan (إنما أنت مهذب).

Selain dari tujuh masalah di atas, maka boleh mendahulukan atau mengakhirkan mubtada.

\section{Wajib Menghilangkan Mubtada}

Mubtada wajib dihilangkan dalam hal-hal sebagai berikut:

a. Apabila mubtada ikut kepada Sifat yang marfu' dengan tujuan memuji atau menghina atau sebagai rasa iba dan saying, contohnya (مررت بزيذٍ الكريُ3) mubtadanya dihilangkan karena disifati oleh sifat yang rafa', asalnya adalah (هر ترك الكريم). Contoh lain ( ابتعد عن اللئيم الخبيث) jauhilah dari orang jahat yang jelek sifatnya), asalnya adalah (هو الخبيث) mubtada nya wajib dihilangkan karena disifati oleh sifat yang marfu".

b. Jika menunjukkan jawaban terhadap sumpah, contohnya (في ذمني لأقولن الصدق) asalnya adalah (في ذمني عهد) dengan menghilangkan mubtadanya yaitu 'ahd.

c. Jika khabarnya adalah mashdar yang mengganti fi'ilnya, contohnya (صبر جير ' دميل) asalnya adalah (صبري صبر جمل) maka wajib menghilangkan mubtadanya.

d. Jika khabarnya dikhususkan pada pujian atau cercaan setelah kata Ni'ma (نعم) dan Bi'sa (بئس) dan terletak diakhir, contohnya (نعم الطالب محمد = alangkah baiknya pelajar yaitu Muhammad) dan ( بئس الطالب الكسول = alangkah buruknya pelajar yang pemalas), muhammad dan kusul pada contoh di atas adalah khabar dari mubtada yang dihilangkan, asalny adalah (هو محمد) dan (هو الكسول).

Selain dari empat masalah ini, mubtada juga kebanyakan dihilangkan jika terletak setelah kata qaul (berkata), contohnya (ويقولون طاعة) mubtadanya dihilangkan,

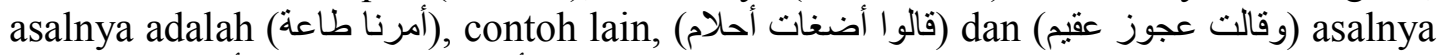
adalah (هي أضغات) dan (أنا عجوز). Atau mubtadanya terletak setelah Fa sebagai jawban dari syarat, contohnya (هو إن يخالطو هم فإخو انكم) asalnya adalah (هن (فهم إخو انكم). 


\section{Boleh Menghilangkan Mubtada}

Mubtada boleh dihilangkan dan dihapus sebagai jawaban atas pertanyaan orang yang bertanya (كيف محمد)?, dan jawabnya (بخير) aslinya adalah (هو بخير), atau Mubtada itu boleh dihilangkan apabila ada kalimat atau kata yang menunjukkan tentangnya, contohnya firman Allah SWT (من عمل صالحا فلنفسه ومن أساء فعليها) kata Falinafsihi kedudukannya rafa' khabar dan dhamir Ha majrur bil idhafah sedangkan mubtadanya mahzuf (dihilangkan) begitu juga pada wa man asaa fa'alaiha, asalnya adalah ( من عمل

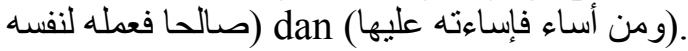

Dan boleh juga menghilangkan Mubtada dan khabarnya apabila ada dalil yang

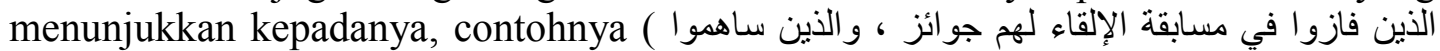

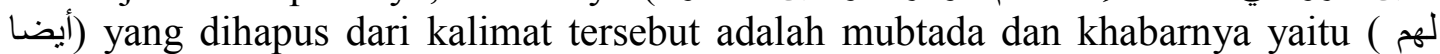
(جوائز) aslinya haruslah (والذين ساهموا أيضا لهم جوائز) dihapus karena telah dijelaskan pada kalimat sebelumnya.

\section{Khabar Yang Disertai $F a^{\prime}$ (ف) al-jaza' atau al-jawab}

Huruf $f a^{\prime}$ (ف) al-jaza' atau al-jawab yang masuk pada khabar berfungsi untuk menguatkan makna antara mubtada' dan khabar. Adapun struktur jumlah ismiyah yang kadang-kadang khabarnya disertai $f a{ }^{\prime}$ (ف) al-jaza' atau al-jawab adalah :

a. Apabila mubtada' menunjukkan makna 'samar' dan 'umum' seperti isim



b. Apabila khabar mubtada terdiri dari jumlah atau syibhul jumlah ${ }^{15}$ contoh: التاجِ فَهُجِوَ فِى السُّوقِ

Struktur jumlah ismiyah di atas khabarnya wajib disertai $f a{ }^{\prime}$ (ف) al-jaza' atau al-

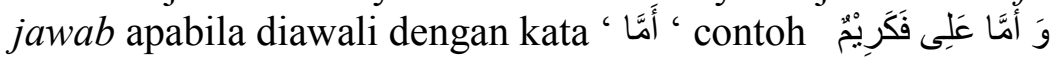

\section{Wajib mendahulukan Khabar}

Khabar wajib di dahulukan dari mubtada dalam keadaan sebagai berikut:

a. Apabila mubtada nya adalah isim nakirah yang semata-mata tidak untuk في (memberitahukan dan khabarnya adalah jar wal majrur atau dharf, contohnya (عندنا ضيف = di sekolah ada para guru), ada tamu). Jika mubtadanya nakirah dengan maksud untuk memberitahukan maka hukumnya boleh didahulukan atau pada tempatnya semula, contohnya (صديق قديم عندنا).

b. Jika khabarnya adalah istifham (kata Tanya) atau disandarkan pada kata Tanya, contohnya (كيف حالك = bagaimana kabarmu), (ابن من هذا = anak siapa ini) atau ( = jam berapa perginya).

c. Apabila ada dhamir yang berhubungan atau bergandengan dengan mubtada sedangkan kembalinya dhamir tersebut kepada khabarnya atau sebagian dari khabarnya, contohnya, (في المدرسة طلابها =di sekolah ada murid-murid-nya), (في di tama nada anak-anak-nya), dhamir yang ada pada mubtada kembali kepada khabarnya.

\footnotetext{
${ }^{15}$ Duktur Abduh Arrajihi, Al-Tathbiq Al-Rajihi, (Bairut: Dar al-Nahdhah al-Arabiyah, 1985), h. 100
} 


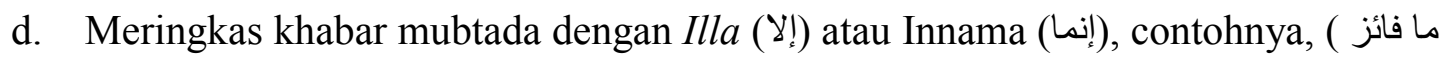
إنما فائز محمد = yang menang adalah Muhammad), dalam contoh ini kata faiz diringkas atau dipendekkan sebagai sifat dari Muhammad.

\section{Boleh mendahulukan atau mengakhirkan khabar}

Boleh mendahulukan khabar (khabar muqaddam) ${ }^{16}$ atau mengakhirkannya,

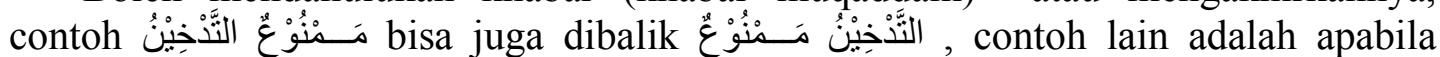
khabarnya sebagai pengkhususan setelah kata $\mathrm{Ni}$ ' $\mathrm{ma}$ (نعم) dan $\mathrm{Bi}$ 'sa (بئس), contohnya alangkah buruknya perbuatan khianat), Muhammad di sini bisa menjadi mubtada muakkhar dan jumlah fi'liyah sebelumnya adalah khabar muqaddam, dan bisa saja mubtadanya dihilangkan dan Muhammad di sini adalah khabarnya, karena apabila pengkhususan setelah ni' ma dan bi' sa didahulukan atas fi'ilnya maka ia adalah mubtada dan jumlah fi'liyahnya adalah khabar muakhhar oleh sebab itu boleh didahulukan atau diakhirkan.

\section{Boleh tidak menyebutkan khabar}

Khabar boleh dihilangkan apabila terletak setelah Iza al fajaiyah (tiba-tiba), contohnya (وصلت فإذا المطر =saya keluar tiba tiba ada harimau), ورجت فإذا الأسد = saya sampai tiba-tiba hujan), khabarnya dihilangkan, asli dari kalimat tersebut adalah ( إذإذا (إذا (الأسد حاضر dan (فإذا المطر منهمر). Apabila ada dalil yang menjelaskannya maka khabar pun boleh dihilangkan, yang dapat ditemukan pada jawaban dari pertanyaan, misalanya ada yang bertanya (من غائب (عiapa yang alpa?), jawabannya (عليّ) dengan menghapus khabarnya yaitu (عليّ غائب) karena telah dijelaskan pada pertanyaannya. Dan apabila jumlah ismiah mengikuti (athf) pada jumlah ismiah yang tidak dihilangkan khabarnya, maka boleh menghilangkan khabar pada jumlah ismiah yang ma'thuf, contohnya (محمد مجتهد وأحمد =muhammad rajin dan ahmad juga), asal dari kalimat di atas (وأحمد مجنهـ), dihilangkan khabar jumlah ismiah yang ma'tuf karena telah dijelaskanpadasebelumnya.

\section{Wajib tidak menyebutkan Khabar} berikut:

Adapun tempat-tempat dimana khabar itu wajib dihilangkan adalah sebagai

a. apabila mubtadanya adalah isim yang sharih yang menunjukkan pada sumpah, contohnya (لعمرك لأشهدن الحق = demi hidupmu saya bersaksi dengan kebenaran), khabarnya wajib dihilangkan, asalnya adalah (لعمرك قنمي).

b. Khabarnya menunjukkan pada sifat yang mutlak artinya sifat tersebut menunjukkan akan keberadaan dari sesuatu, dan hal itu terdapat pada kata yang bergandengan dengan jar majrur atau dharf, contohnya (الماء في الإبريق) = air berada di dalam teko), (الكتاب فوق المكتب = buku berada di atas meja), yang menunjukkan khabarnya telah dihilangkan yaitu (موجود). Dan apabila

\footnotetext{
${ }^{16}$ Maslani, Qiro'atul Kutub, (Cet. I; Jakarta Pusat: Direktorat Jenderal Pendidikan Islam Departemen Agama Republik Indonesia, 2009), h. 44
} 
mubtadanya terletak setelah Lau la (لو لا) maka khabarnya yang berarti keberadaan pun wajib dihilangkan, contohnya (لولا لو اله لصدمت السيارة الطفل) jika tidak ada Allah, maka mobil akan menabrak anak itu), khabar yang dihilangkan adalah kata (موجود) pada contoh ini.

c. Jika mubtadanya adalah mashdar atau isim tafdhil yang disandarkan pada mashdar dan setelahnya bukanlah khabar melainkan hal (حال) yang menduduki tempatnya khabar, contohnya (تشجيعي الطالب متفوقا = saya mendukung pelajar yang berprestasi), (: أفضل صلاة العبد خاشعا sebaik-baik shalatnya sorang hamba dalam

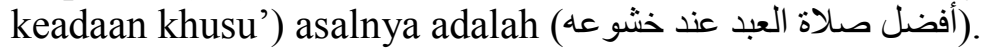

d. Khabarnya terletak setelah huruf Wau (واو (مع) yang berarti dengan/bersama), contohnya, (كل طالب وزميله semua pelajar bersama kawanya), wau di sini berarti bersama sehingga khabarnya dihilangkan, dan khabar yang dihilangkan adalah kata (مقرونان).

Inilah bentuk-bentuk jumlah ismiyah yang dikenal dalam kaidah bahasa Arab. Dengan demikian setiap jumlah ismiyah yang disusun dalam bahasa Arab mesti berdasarkan pada salah satu bentuk-bentuk jumlah ismiyah sebagaimana yang telah diuraikan di atas.

\section{KESIMPULAN}

Berdasarkan uraian di atas dapat disimpulkan bahwa :

1. Mubtada' sebagai salah satu unsur jumlah ismiyah adalah umumnya terdiri dari isim ma'rifah, sebagian kecil terdiri dari isim nakirah, dan mubtada' juga dapat terbentuk mashdar muawwal. Sedangkan khabar sebagai unsur lain daripada jumlah ismiyah adalah dapat terdiri dari kata, kalimat (jumlah), maupun terdiri dari keterangan (syibhul jumlah).

2. Bentuk-bentuk jumlah ismiyah adalah terdiri dari lima macam yaitu, pertama; mendahulukan mubtada' dari pada khabar, kedua; mendahulukan khabar dari pada mubtada', ketiga; mubtada' tidak disebutkan sehingga yang tampak dalam kalimat hanyalah khabar, keempat; khabar tidak disebutkan sehingga yang tampak dalam kalimat hanyalah mubtada', dan kelima; mubtada' yang beramal seperti fi'ilnya sehingga yang menjadi pengganti khabarnya adalah fa'ilnya dan kadang-kadang halnya.

\section{DAFTAR PUSTAKA}

Abubakar Muhammad, Ilmu Nahwu : Teori Praktis Untuk Menguasai Tata Bahasa Arab, (Surabaya: Karya Abditama, 1996) al-Jail)

Ahmad Qabbisy, al-kāmil fì 'Ilm al-Nahw wa al-Śarf wa al-'Irāb, (Bairut-Libnān: Dār

Ahmad Yazid dan Umar Hubeis, Belajar Mudah Ilmu Nahwu Shoraf, (jilid I , Cet. I; Surabaya: Pustaka Progressif, 2011) 
Al-Duktur Al-Fakhriy Al-hajj Mustafa Muhammad Nuri, LAS wa Al-Hajjah Hafsah Intan, LC, Al-Arabiyah Al-Muyassarah, (Cet. I; Makassar: Pustaka Arif, 2008)

Al-syeikh Ahmad Al-hamlawi, Syatz Al-'urf fi Al-sharf, (Cet. XVI; Mesir: Syirkah Maktabah Mushthafa al-Tsaniy al-Halbiy wa Auladuh, 1384 H/1965 M) 1985)

Duktur Abduh Arrajihi, Al-Tathbiq Al-Nahwi, (Bairut: Dar al-Nahdhah al-Arabiyah,

Fuād Ni'mah, Mulakhkhaś Qawā'id al-Lughah al-Arabiyah, (Bairut: Dār al-Ṣaqāfah al-Islāmiyah, t.th)

Jurjis Isa Al Asmar, Qamus al-'Irab, (Dar al-Ilmi li al-Malayin; Bairut : t.th)

Maslani, Qiro'atul Kutub, (Cet. I; Jakarta Pusat: Direktorat Jenderal Pendidikan Islam Departemen Agama Republik Indonesia, 2009)

Rappe, Ilmu Nahwu Dasar Dan Pola-Pola Penerapannya Dalam Kalimat (Cet. I; Makassar: Alauddin University Press, 2013)

Syeikh Syamsuddin Muhammad Arra'ini, Mutammimah Ajurumiyah diterjemahkan oleh Moch. Anwar dkk dengan judul Ilmu Nahwu, (Cet.XIX; Bandung : Sinar Baru Algesindo, 2016) 